\title{
EXPLORE
}

\section{Aplikasi E-Marketing Panglong Kayu Menggunakan Metode Colaborative Filtering}

\author{
Erlangga, Mar Hidayati Anggraini, Fenty Ariani, Yuthsi Aprilinda \\ Program Studi Sistem Informasi, Fakultas Ilmu Komputer \\ Program Studi Informatika, Fakultas Ilmu Komputer \\ Universitas Bandar lampung \\ Bandar Lampung, Indonesia \\ erlangga@ubl.ac.id,mar.15411056@student.ubl.ac.id, fenty.ariani@ubl.ac.id, Yuthsi.aprilinda@ubl.ac.id
}

\begin{abstract}
The wood processing business is increasing, and is one of the potential business opportunities in the current era. Wood processing industries such as teak processing, wood construction, creative industries also use wood materials. However, many businesses stop because they are lagging behind with technological advancements, including wood processing. Problems agreed, most of the long-term entrepreneurs are still supported by traditionally managed marketing. The product marketing process is done manually only through direct interaction with consumers. In addition, product marketing is only focused on certain places such as coming directly to the place of craftsman or when there is an exhibition. For this reason, the design and development of a panglong kayu e-marketing application is needed to find the information needed in a fast and accurate time. Application built using Collaborative Filters. Based on the results of research using panglong wood e-marketing in the city of Bandar Lampung, it provides all information about the market, provides information for customers, and provides users in providing information about panglong wood based on assessments given by other users
\end{abstract}

Keywords : E-marketing, Panglong Kayu, Rating, Collaborative Filtering

\begin{abstract}
Abstrak- Usaha pengolahan kayu semakin makin berkembang, dan menjadi salah satu peluang bisnis yang berpotensial di zaman sekarang. Industri pengolahan kayu seperti pengolahan kayu jati, kayu konstruksi bangunan, industri kreatif juga banyak yang menggunakan bahan kayu. Namun, Banyak usaha-usaha yang terpaksa terhenti karena tertinggal dengan kemajuan teknologi termasuk usaha pengolahan kayu. Permasalahan yang dihadapi, kebanyakan pengusaha panglong masih sepenuhnya berharap pada pemasaran yang dikelola secara tradisional saja. Proses pemasaran produk tersebut dilakukan secara manual hanya melalui interaksi langsung dengan konsumen. Selain itu, pemasaran produk hanya terfokus pada tempat-tempat tertentu seperti datang langsung ke tempat pengrajin atau ketika ada pameran. Untuk alasan ini, desain dan pengembangan aplikasi e-marketing panglong kayu diperlukan untuk menemukan informasi yang dibutuhkan dalam waktu yang cepat dan akurat. Aplikasi dibangun menggunakan pendekatan Collaborative Filtering. Berdasarkan hasil penelitian dengan menerapkan aplikasi e-marketing panglong kayu di Kota Bandar Lampung dapat memperluas pangsa pasar, memberikan kemudahan dalam pemberian informasi kepada konsumen, dan memudahkan pengguna dalam memberikan rekomendasi panglong kayu berdasarkan rating yang telah diberikan oleh para pengguna lainya.
\end{abstract}

Kata Kunci : E-marketing, Panglong Kayu, Rating, Collaborative Filtering

\section{Pendahuluan}

Pesatnya perkembangan dan pertumbuhan teknologi informasi memiliki dampak positif pada perusahaan atau organisasi yang bergerak di industri, pemasaran dan jasa. Keberadaan teknologi informasi telah memberikan perubahan yang sangat signifikan dalam transformasi bisnis dari tradisional ke digitalisasi. Kondisi ini memungkinkan pengurangan biaya sehingga meningkatkan jumlah interaksi menjadi lebih mudah. Ini menjadi lebih mudah karena tidak perlu hadir secara fisik, ada lebih banyak alternatif, lebih murah, dan memiliki peluang untuk memperluas pemasaran [1].

Usaha pengolahan kayu tidak akan pernah lekang dimakan waktu bahkan akan semakin berkembang dan menjadi salah satu peluang bisnis yang potensial. Usaha pengolahan kayu tetap menjadi pilihan usaha terbaik dari masa ke masa. Bahkan saat ini tak sulit untuk menemukan pengusaha pengolahan kayu. Kayu merupakan bahan baku olahan yang banyak dan mudah untuk dibentuk sesuai dengan keinginan dan kebutuhan. Beberapa 
industri seperti konstruksi bangunan, industri kreatif juga banyak yang menggunakan bahan kayu. Namun banyak juga yang terpaksa berhenti karena tertinggal oleh kemajuan teknologi dan sistem informasi.

Internet memiliki kemampuan untuk melakukan berbagai kegiatan termasuk memasarkan produk online kepada siapa saja yang membutuhkan dan terhubung ke internet. Ini disebut e-marketing, pemasaran elektronik yang menghadirkan banyak kemudahan bagi perusahaan, pelanggan, dan mitra bisnis [2].

E-marketing yang efektif akan mengubah pengetahuan masyarakat tentang ketersediaan barang / jasa. Elastisitas permintaan barang/jasa sangat dipengaruhi oleh kegiatan pemasaran yang kemudian dipromosikan secara intensif melalui media massa dalam bentuk pemasaran dengan teknik modern [3]. Bagi perusahaan, pemasaran secara elektronik dapat memperluas pasar dan memberikan kemudahan dalam menyajikan informasi. Bagi pelanggan, mencari barang/jasa yang diinginkan dapat diperoleh dengan mudah tanpa harus meninggalkan kantor atau rumah.

Masalah yang ditemukan adalah kurangnya pengembangan bisnis saat ini. Sebagian besar pengusaha panglong masih mengandalkan pemasaran tradisional, yaitu word of mouth marketing; pemasaran dari mulut ke mulut. Sistem pemasaran seperti ini masih sangat manual, harus berinteraksi langsung dengan konsumen dan masih terfokus pada lokasi tertentu saja seperti ketika ada pameran saja atau datang langsung ke pengrajin. Terkadang penjual kesulitan menemukan alamat konsumen yang tidak jelas. Masalah lain calon pembeli seringkali merasa kesulitan mencari berbagai informasi kebutuhan produk, informasi tentang harga, dan proses pencatatan barang inventaris yang masih dilakukan dengan cara sederhana, dimana ketika diperiksa oleh pemilik panglong secara langsung, stok barang yang tidak masuk sesuai dengan kondisi nyata yang ditemukan oleh pemilik panglong.

Oleh karena itu diperlukan suatu sistem informasi pemasaran online yang dapat menjangkau pangsa pasar yang lebih luas dan memfasilitasi promosi dan pemasaran produk pengolahan kayu. Output yang dihasilkan berupa informasi produk, informasi pesanan terperinci, laporan stok, dan laporan transaksi penjualan. Aplikasi ini bertujuan untuk membuat sistem pencatatan terkomputerisasi yang dapat memfasilitasi pemilik jangka panjang dalam menemukan informasi yang diperlukan dalam waktu cepat dan akurat untuk merancang dan mengembangkan aplikasi e-marketing online di Kota Bandar Lampung, sehingga dapat memperluas pemasaran dan dapat memesan kayu kapan dan dimana saja, dan untuk mengetahui analisis dan implementasi aplikasi emarketing online di Kota Bandar Lampung, dan untuk membuat sistem inventaris yang terkomputerisasi sehingga mudah ditemukan.

Manfaat penelitian ini untuk pemilik bisnis dapat memperluas pasar dan memudahkan pemilik bisnis dalam mensajikan informasi kepada pelanggan mereka. Untuk pelanggan sendiri, produk yang diinginkan dapat diperoleh dengan mudah tanpa harus khawatir pergi meninggalkan rumah atau kantor, pelanggan cukup dengan mengakses aplikasi, memilih produk, memesan produk, melakukan transaksi dan menunggu produk dikirim.

\section{Dasar Teori}

\section{A. Penelitian Serupa}

Penelitian dengan judul Pemanfaatan Aplikasi Emarketing pada PT. JEAH untuk memenangkan persaingan usaha menyatakan bahwa aplikasi e-marketing cocok untuk digunakan di perusahaan yang menginginkan adanya perluasan pasar mereka, karena aplikasi ini diharapkan mampu menjangkau lebih banyak konsumen. Menggunakan script bahasa Microsoft Active Server Pages (ASP). Sistem dibangun berbasis client-server [2]. Sementara aplikasi panglong kayu menggunakan script bahasa pemrograman PHP. Sistem dibangun berbasis webview.

Penelitian dengan judul Perancangan dan Pengembangan Web dengan Strategi E-marketing pada PT Columbindo Perdana menyatakan bahwa sistem ini dapat dipakai sebagai wadah untuk mendistribusikan informasi supaya melebarkan pangsa pasar menjadi lebih luas. Menggunakan kerangka kerja 7C, pengembangan sistem ini menggunakan pendekatan Rational Unified Process (RUP) [4]. Sementara aplikasi panglong kayu menggunakan Framework Codeigneter. Metode pengembangan sistem menggunakan waterfall.

Penelitian dengan judul Perancangan E-marketing UMKM Kerajinan Tas menyatakan bahwa sistem emarketing mampu masuk diberbagai lapisan masyarakat, penjual dapat berhubungan secara intens dengan pembeli tanpa khawatir dibatasi oleh ruang waktu. Dengan semakin banyak pembeli dari sistem pemasaran tradisional sadar akan ini, yang pada gilirannya dapat meningkatkan ekonomi masyarakat, terutama para pengrajin tas. Belum menggunakan filtering pada pencarian item barang. Pembahasan produk yang dipasarkan berupa kerajinan tas [5]. Sementara aplikasi panglong kayu menggunakan metode pencarian item barang yaitu metode Colaborative Filtering. Pembahasan produk yang dipasarkan berupa panglong kayu.

Penelitian dengan judul Peran E-marketing dalam Memediasi Pengaruh Orientasi Pasar Terhadap Kinerja Bisnis menyatakan bahwa market orientation membawa pengaruh positif dan memegang peranan penting terhadap kinerja bisnis dan e-marketing itu sendiri. Penelitian ini menganalisis peran e-marketing pada lapisan masyarakat [6]. Sementara aplikasi panglong kayu menerapkan e-marketing pada sistem pemasaran sample panglong kayu di Bandar Lampung. 


\section{B. Metode Pengembangan Sistem}

Metode pengembangan model sistem Waterfall, disebut juga siklus hidup klasik, adalah pendekatan sistematis dan berurutan untuk pengembangan perangkat lunak. Terdiri dari 5 tahap; Komunikasi (persyaratan pengumpulan), Perencanaan (estimasi, penjadwalan, pelacakan), Pemodelan (analisis desain), Konstruksi (sistem pengkodean dan pengujian), Penyebaran (pengiriman, dukungan, umpan balik) [7].

\section{Metode Collaborative Filtering [8]}

Collaborative Filtering (CF) adalah teknologi sistem rekomendasi paling sukses saat ini, dikenal dan disukai banyak orang karena sesuai dengan kebutuhan masyarakat pada umumnya. Penggunaan metode CF sangat sukses untuk berbagai sistem rekomendasi di internet. Teknik statistik disini digunakan untuk menemukan satu kelompok pengguna yang dikenal sebagai neighbors, dimana setiap pengguna memiliki opini dan minat yang sama dengan pengguna yang ditargetkan (yaitu, mereka yang memiliki beberapa item dengan peringkat yang sama atau memiliki kecenderungan untuk menyukai item yang sama). Setelah lingkungan neighbors terbentuk, sistem akan mengindahkan beberapa algoritma untuk membuat rekomendasi.

CF adalah proses memfilter atau mengevaluasi suatu barang menggunakan pendapat orang lain. Dalam prosesnya, CF menyaring data berdasarkan kesamaan karakteristik pengguna sehingga dapat menyediakan informasi baru kepada pengguna karena informasi yang disediakan oleh sistem mengacu pada pola satu kelompok pengguna yang hampir serupa. Pilihan yang berbeda dari beberapa anggota kelompok menjadi sumber informasi baru yang tidak mengesampingkan kemungkinan berguna bagi anggota kelompok lainnya.

Proses pembuatan rekomendasi umumnya terdiri dari 3 langkah: menemukan pengguna yang sama, membuat neighbors, dan menghitung prediksi berdasarkan neighbors yang dipilih. Sementara itu bentuk peringkat dalam penyaringan kolaboratif juga terdiri dari 3 bentuk, yaitu model peringkat skalar yang terdiri dari peringkat numerik (seperti memilih 1-5), model peringkat biner (seperti setuju atau tidak setuju), model peringkat unary (dapat menunjukkan bahwa pengguna telah melakukan pengamatan, membeli atau menilai barang dengan benar.

Menurut teori dan kepraktisan, algoritma CF dibagi menjadi dua yaitu algoritma probabilistik dan algoritma non-probabilistik. Dikatakan probabilistik jika suatu algoritma didasarkan pada model kemungkinan itu sendiri. Algoritma ini mewakili persebaran kemungkinan ketika menentukan prediksi peringkat atau daftar peringkat. Diantaranya adalah Nearest Neighbor Algorithm (NNA) yang merupakan algoritma yang paling sering digunakan dan merupakan algoritma nonprobabilistik. Algoritma NNA pun dibagi menjadi dua, yaitu berbasis item dan berbasis pengguna.

Algoritma User-Based Collaborative Filtering bekerja berdasarkan dugaan bahwa setiap pengguna adalah bagian dari grup yang memiliki kesamaan dengan pengguna lain. Dasar pertimbangan yang digunakan bahwa setiap rekomendasi yang didapatkan berlandaskan pada item yang disukai oleh setiap pengguna. Item yang disarankan adalah hasil rekomendasi sesuai dengan apa yang disukai pengguna lain. Dengan kata lain, pengguna yang memiliki hubungan (atribut) yang sama akan tertarik ke item yang sama.

Algoritma Item-Based Collaborative Filtering adalah metode rekomendasi berdasarkan pada kesamaan antara peringkat produk dan produk yang dibeli. Dari tingkat kesamaan produk, maka dibagi dengan parameter dari kebutuhan pelanggan guna mendapatkan nilai manfaat produk. Produk yang punya nilai utilitas tertinggi akan digunakan sebagai rekomendasi [9].

Langkah penting dalam algoritma penyaringan kolaboratif berbasis item adalah penghitungan kesamaan antar item dan pemilihan item yang paling hampir sama. Dasar untuk menghitung kesamaan antara dua item adalah memisahkan pengguna yang telah memberikan penilaian pada kedua item, selanjutnya menerapkan teknik kesamaan item untuk mendapatkan nilai kesamaan. Setelah mendapatkan serangkaian produk yang sangat mirip, proses prediksi dilakukan yang memperkirakan nilai tingkat pengguna. Prediksi yang diprediksi adalah produk yang belum dinilai oleh pengguna. Jika nilai prediksi sangat tinggi, ini berarti pengguna target mungkin tertarik pada item tersebut [10].

\section{Metodologi}

Penelitian ini dilakukan melalui beberapa tahap yaitu Problem Identification - tahap awal penelitian dengan cara melakukan kajian literatur dan pengidentifikasian masalah; Intervention - tahap pengumpulan data, analisis terhadap sistem yang berjalan saat ini dan membuat rancangan konseptual dan rancangan interface sistem yang akan diusulkan; Evaluation - tahap pengkodingan sistem dan pengujian terhadap sistem yang diusulkan; Reflection and Learning $\neg-$ tahap implementasi dan maintenance sistem baru tersebut.

Usecase diagram Gambar 1 menjelaskan peran aktor atau peran masing-masing pengguna dalam aplikasi panglong ini.

Class diagram Gambar 2 menjelaskan model yang digunakan dalam mendesain atribut dan fungsi yang akan digunakan untuk membangun aplikasi panglong ini. 


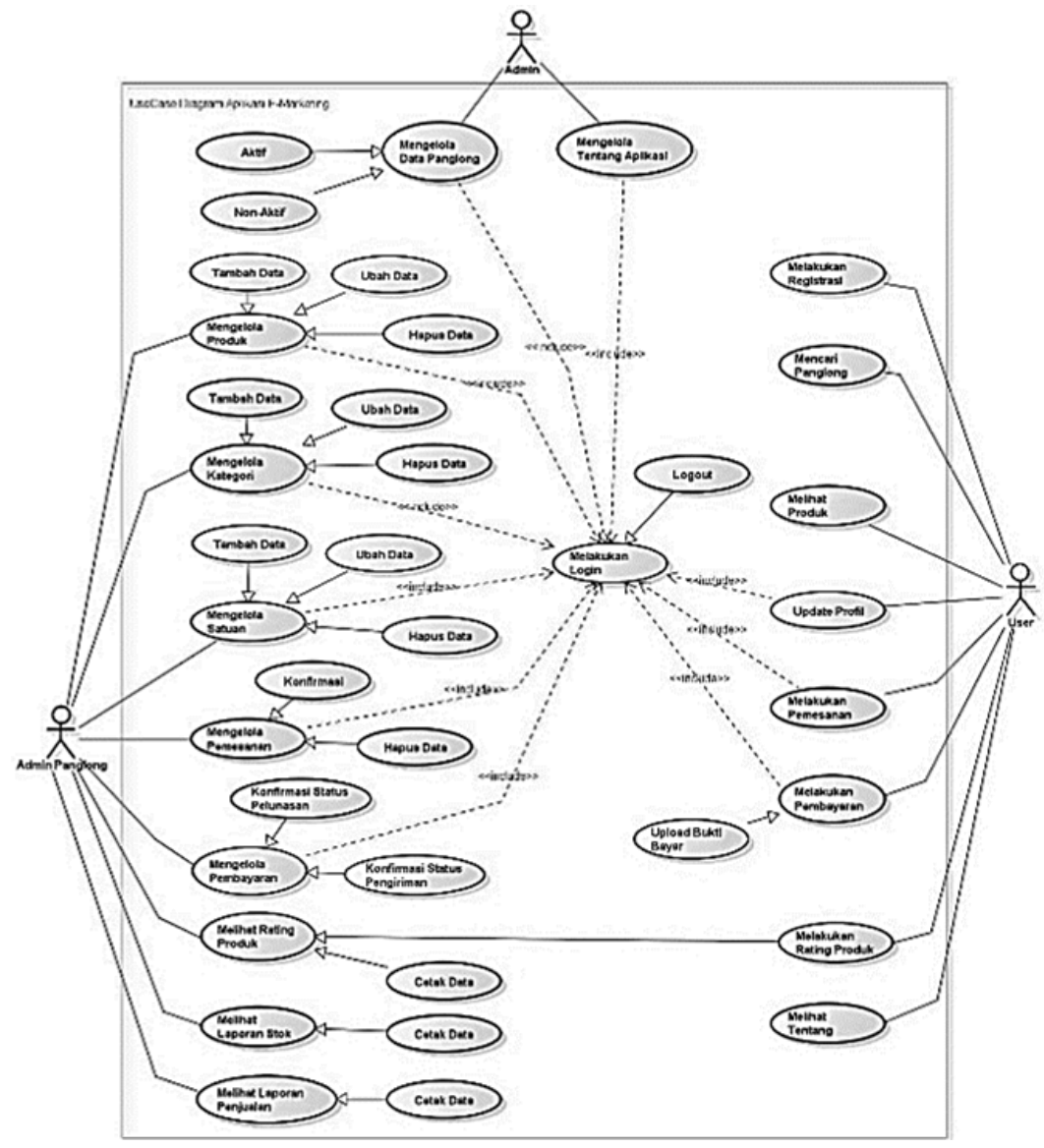

Gambar 1. Usecase Diagram Aplikasi Panglong

Class Diagram Aplikasi E-Marketing

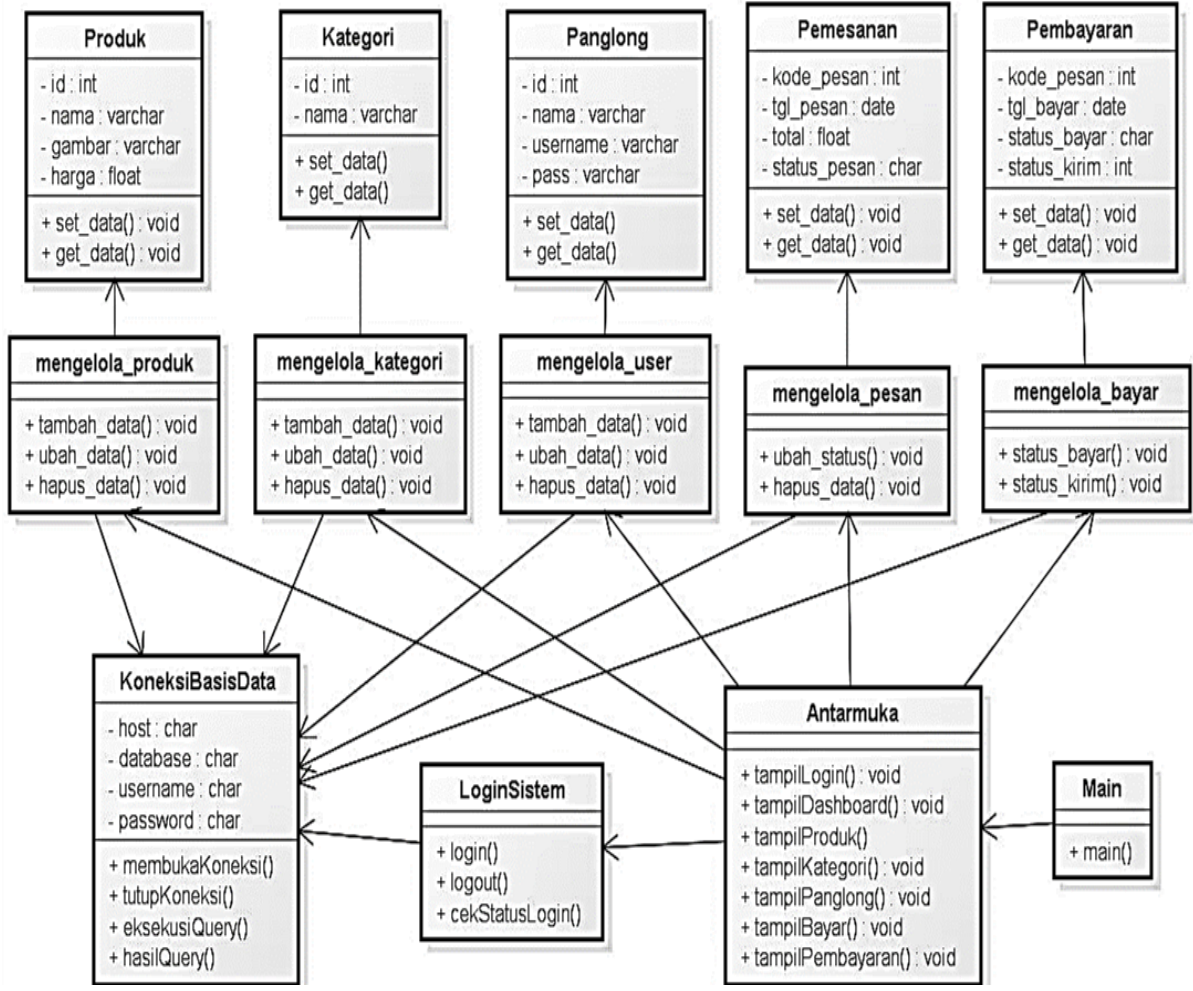

Gambar 2. Class Diagram Aplikasi Panglong 
4. Hasil dan Pembahasan

\section{A. Implementasi Item-Based Collaborative Filtering}

Tahap awal melakukan penghitungan pada kesamaan antara item yang telah dinilai oleh pengguna, bentuk penilaian diberi peringkat pada skala 1-5.

Tabel 1. Hasil Skenario Rating

\begin{tabular}{lllllllll}
\hline No. & $\begin{array}{l}\text { Nama } \\
\text { Pelanggan }\end{array}$ & $\begin{array}{l}\text { Produk } \\
\text { Kayu A }\end{array}$ & $\begin{array}{l}\text { Produk } \\
\text { Kayu B }\end{array}$ & $\begin{array}{l}\text { Produk } \\
\text { Kayu C }\end{array}$ & $\begin{array}{l}\text { Produk } \\
\text { Kayu D }\end{array}$ & $\begin{array}{l}\text { Produk } \\
\text { Kayu E }\end{array}$ & $\begin{array}{l}\text { Produk } \\
\text { Kayu F }\end{array}$ & $\begin{array}{l}\text { Rata-rata } \\
\text { Rating }\end{array}$ \\
\hline 1 & Nana & 0 & 5 & 4 & 3 & 0 & 0 & 4.00 \\
\hline 2 & Vera & 0 & 0 & 3 & 2 & 4 & 1 & 2.50 \\
\hline 3 & Dila & 0 & 3 & 0 & 0 & 0 & 3 & 3.00 \\
\hline 4 & Agus & 4 & 0 & 0 & 1 & 0 & 0 & 2.50 \\
\hline 5 & Angga & 0 & 2 & 2 & 4 & 0 & 5 & 3.25 \\
\hline 6 & Andi & 0 & 5 & 0 & 4 & 0 & 0 & 4.50 \\
\hline
\end{tabular}

Menggunakan persamaan adjusted cosine, berikut adalah persamaan antara produk B dan produk C:

$$
\begin{aligned}
& \operatorname{sim}(i, j)=\frac{N}{M} \cdot \frac{\sum_{u \in U}\left(R_{u, i}-\bar{R}_{i}\right)\left(R_{u, j}-\bar{R}_{j}\right)}{\sqrt{\sum_{u \in U}\left(R_{u, i}-\bar{R}_{i}\right)^{2}} \sqrt{\sum_{u \in U}\left(R_{u, j}-\bar{R}_{j}\right)^{2}}} \\
& \operatorname{Sim}(\mathrm{B}, \mathrm{C})=\frac{(5-4)(4-4)+(2-3,25)(2-3,25)}{\sqrt{(5-4)^{2}+(2-3,25)^{2}} \sqrt{\left(4-4^{2}\right)+(2-3,25)^{2}}} \\
& \operatorname{Sim}(\mathrm{B}, \mathrm{C})=\frac{1,56}{2}=0,78
\end{aligned}
$$

Dalam penghitungan nilai kesamaan, nilai yang dihasilkan dari cosine-adjusted similarity adalah antara +1.0 dan -1.0. Informasi cakupan antara dua item bernilai 0 jika kedua item memiliki nilai kesamaan, nilai mendekati +1.0 jika kedua item cenderung mirip satu sama lain, nilai mendekati -1.0 jika kedua item saling bertentangan satu sama lain.

Selanjutnya melakukan penghitungan kesamaan nilai-nilai tersebut maka didapat tabel kesamaan pada Tabel 2

Tabel 2. Kesamaan antar Produk Kayu

\begin{tabular}{lll}
\hline Produk Kayu 1 & Produk Kayu 2 & $\begin{array}{l}\text { Nilai } \\
\text { Kemiripan }\end{array}$ \\
\hline Produk Kayu A & Produk Kayu B & 0.00 \\
\hline Produk Kayu A & Produk Kayu C & 0.00 \\
\hline Produk Kayu A & Produk Kayu D & -1.00 \\
\hline Produk Kayu A & Produk Kayu E & 0.00 \\
\hline Produk Kayu A & Produk Kayu F & 0.00 \\
\hline Produk Kayu B & Produk Kayu C & 0.78 \\
\hline Produk Kayu B & Produk Kayu D & -0.97 \\
\hline Produk Kayu B & Produk Kayu E & 0.00 \\
\hline Produk Kayu B & Produk Kayu F & -1.00 \\
\hline Produk Kayu C & Produk Kayu D & -0.66 \\
\hline Produk Kayu C & Produk Kayu E & 1.00 \\
\hline Produk Kayu C & Produk Kayu F & -0.95 \\
\hline Produk Kayu D & Produk Kayu E & -1.00 \\
\hline Produk Kayu D & Produk Kayu F & 0.99 \\
\hline Produk Kayu E & Produk Kayu F & -1.00 \\
\hline
\end{tabular}

Langkah selanjutnya adalah membuat nilai taksiran. Setelah mendapatkan satu set item yang sangat mirip berdasarkan pada perhitungan kesamaan, dilakukan proses prediksi yang kemudian akan memperkirakan 
peringkat pengguna untuk item yang belum dinilai oleh pengguna.

Setelah mendapatkan nilai kesamaan antara produk kayu, nilai lebih besar dari nol akan digunakan untuk memperoleh nilai taksiran, karena nilai ini dianggap sebagai batas bawah konektivitas antar produk. Untuk mendapatkan nilai taksiran suatu produk yang belum dinilai oleh pengguna, digunakan persamaan weighted sum. Berikut perhitungan nilai prediksi User1 terhadap produk kayu A:

$$
\begin{gathered}
P_{u, i}=\frac{\sum_{\text {all similar items }, N}\left(S_{i, N} * R_{u, N}\right)}{\sum_{\text {all similar items }, N}\left(\left|S_{i, N}\right|\right)} \\
P(1, A)=\frac{(5 * 0)+(4 * 0)+(3 *-1)+(0 * 0)+(0 * 0)}{|0|+|0|+|-1|+|0|+|0|} \\
P(1, A)=\frac{-3}{1}=-3
\end{gathered}
$$

Setelah melakukan penghitungan terhadap nilai taksiran lainnya menggunakan rumus yang sama seperti di atas, maka didapatkan tabel hasil taksiran pada Tabel 3.

Berdasarkan Tabel 3 ditemukan bahwa pengguna 1 (Nana) mendapat rekomendasi produk kayu E, pengguna 3 (Dila) mendapat rekomendasi produk kayu D, pengguna 4 (Agus) mendapat rekomendasi produk kayu $\mathrm{F}$, dan pengguna 6 (Andi) mendapat produk kayu $\mathrm{C}$.

Tabel 3. Hasil Nilai Taksiran

\begin{tabular}{cccc}
\hline Pelanggan & Produk Kayu (PK) & Prediksi & Rekomendasi PK \\
\hline 1 & A & -3.00 & \\
1 & E & 0.50 & E \\
1 & F & -1.98 & \\
2 & A & -2.00 & - \\
2 & B & -0.22 & \\
3 & A & 0.00 & \\
3 & C & -0.29 & D \\
3 & D & 0.03 & \\
3 & E & -3.00 & \\
4 & B & -1.00 & \\
4 & C & -1.00 & F \\
4 & E & -1.00 & \\
4 & F & 1.00 & \\
5 & A & -4.00 & - \\
5 & E & -2.33 & \\
6 & A & -4.00 & \\
6 & C & 0.88 & C \\
6 & E & -4.00 & \\
6 & F & -0.52 & \\
\hline
\end{tabular}

\section{B. Alur Proses}

Alur flowchart berikut untuk menggambarkan urutan proses dan hubungan antar proses pada aplikasi panglong. 


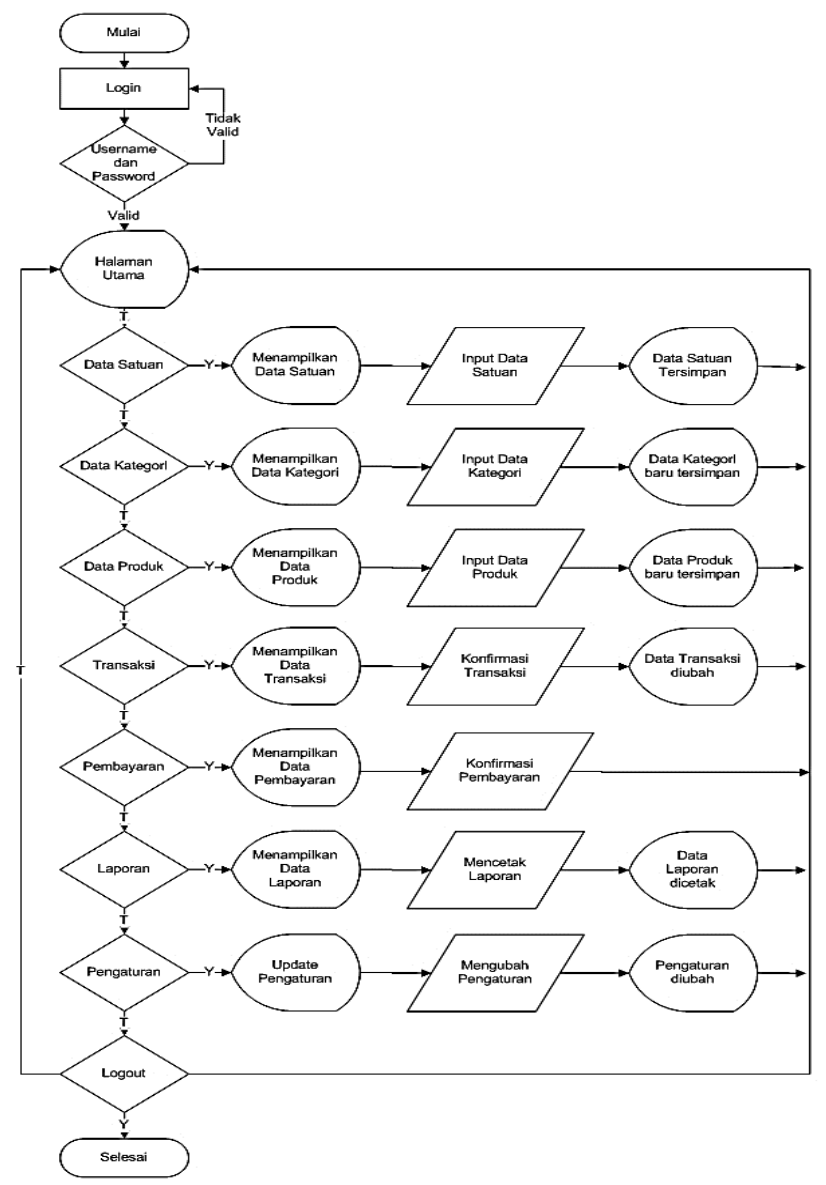

Gambar 3. Flowchart Admin Panglong pada Aplikasi

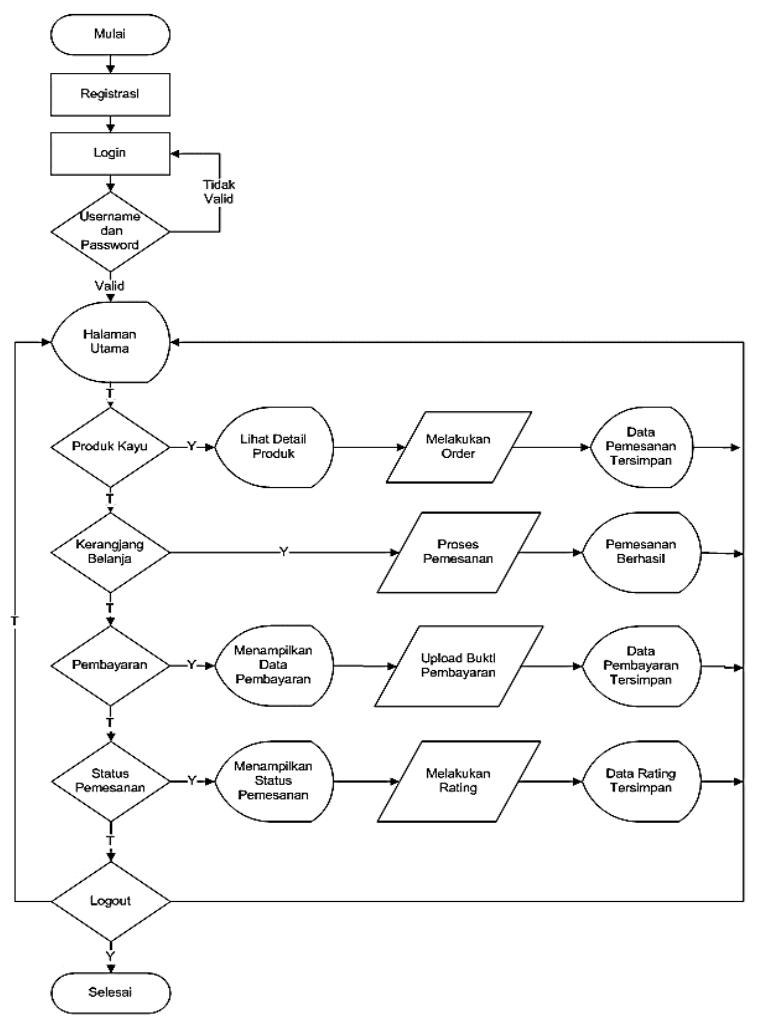

Gambar 4. Flowchart Pelanggan Panglong 


\section{Interface E-Marketing Panglong}

Gambar 5 Halaman Dashboard Administrator berisi opsi menu yang terkait dengan semua program penggunaan aplikasi. Ada beberapa komponen menu pada halaman utama admin seperti Menu dan Pengaturan Data Panglong.

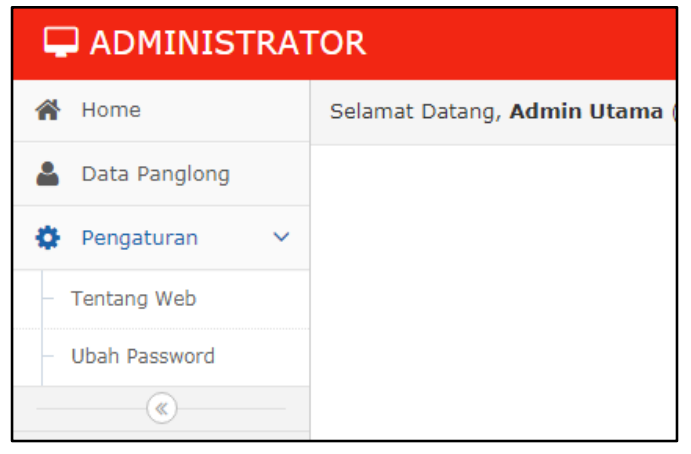

Gambar 5. Dashboard Administrator E-Marketing

Gambar 6 Halaman Dashboard Admin Panglong berisi opsi menu yang terkait dengan semua program penggunaan aplikasi. Ada beberapa komponen menu pada halaman admin utama, seperti Menu Data Unit, Data Kategori, Data Produk, Transaksi, Pembayaran, Laporan dan Pengaturan.

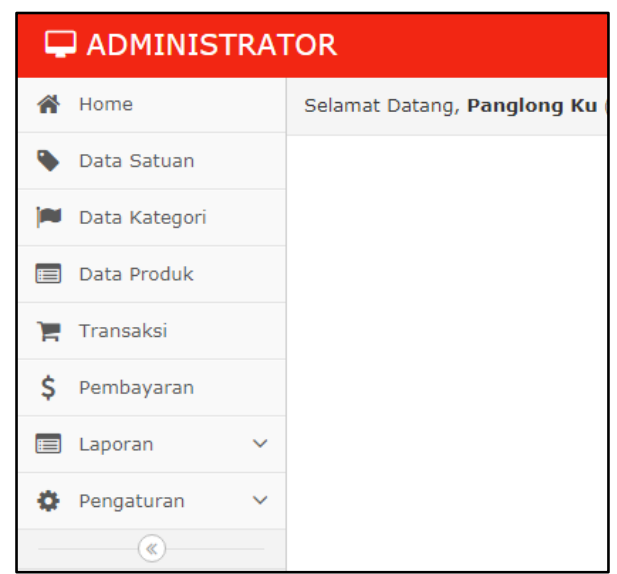

Gambar 6. Dashboard Admin Panglong

Gambar 7 Halaman Beranda untuk pengguna aplikasi emarketing kayu panglong yang berisi opsi menu yang terkait dengan semua program penggunaan aplikasi. Ada beberapa komponen menu pada halaman utama pengguna seperti Menu Status Pesanan, Konfirmasi Pembayaran, Entri Kontak dan Resume Pesanan.

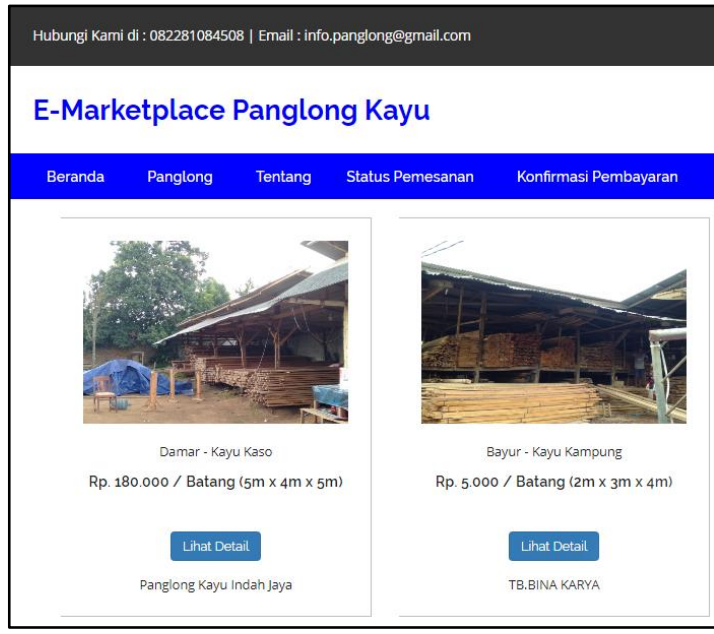

Gambar 7. Halaman Dashboard User Panglong

Gambar 8 adalah halaman untuk memesan barang yang berfungsi untuk melakukan pemesanan. Pada halaman ini ada tombol yang berfungsi untuk memproses pesanan yang akan disimpan dalam database.

Gambar 10 Halaman Input Rating untuk memasukkan data rating. Pada halaman ini ada tombol simpan, tombol simpan berfungsi untuk menyimpan data peringkat yang telah dimasukkan.

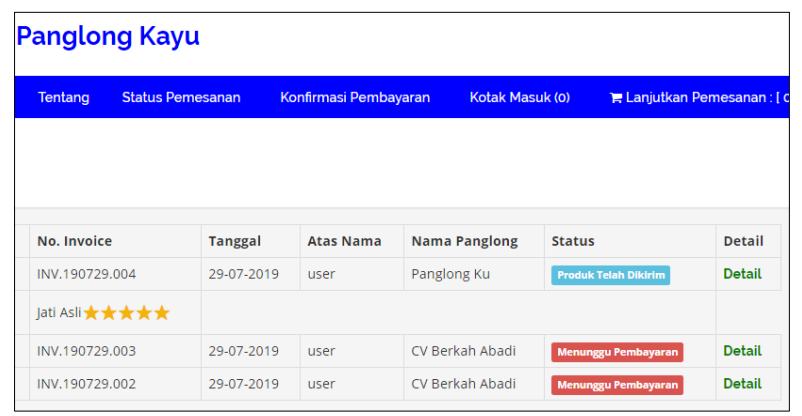

Gambar 10. Halaman Input Rating

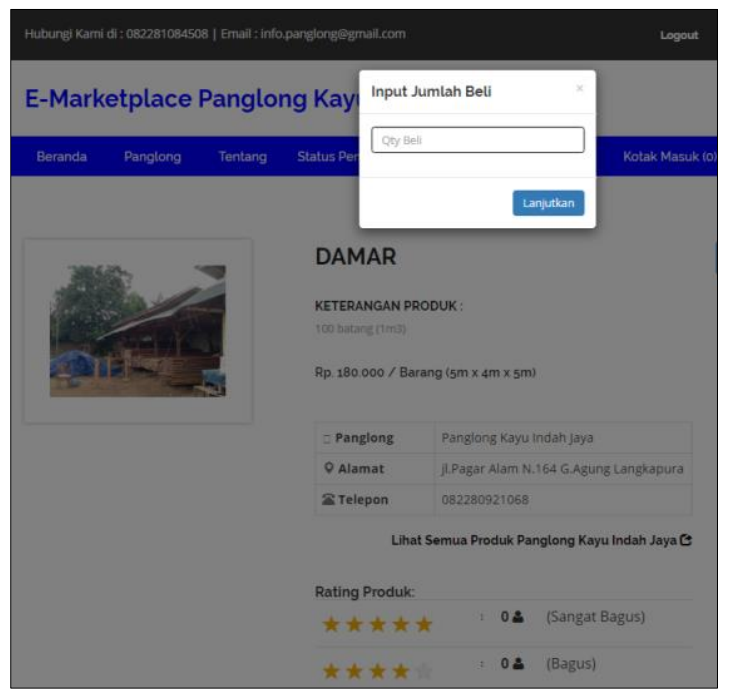

Gambar 8. Halaman Input Pemesanan

Gambar 9 Halaman Input Pembayaran yang berisi Opsi Faktur, Nama Pengirim, Bukti Transfer. Halaman ini berfungsi untuk memasukkan data pembayaran 
pengguna. Di halaman ini ada tombol unggah yang berfungsi untuk menyimpan data pembayaran ke dalam basis data.

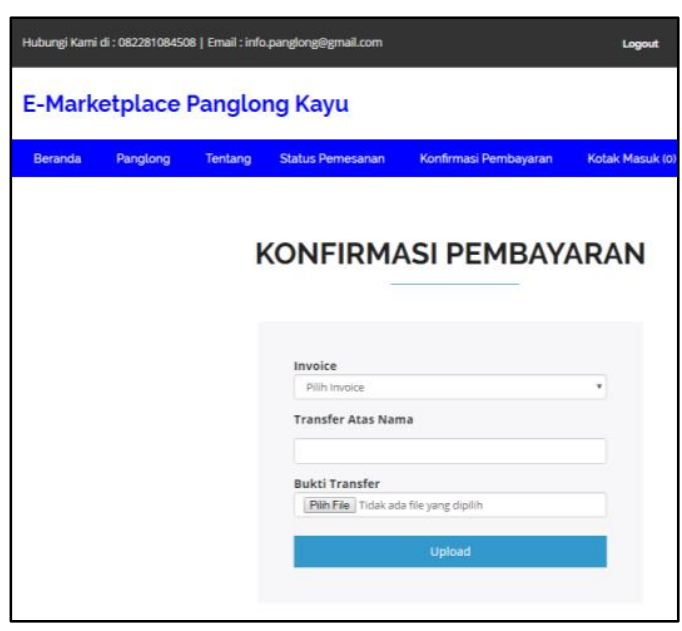

Gambar 9. Halaman Input Pembayaran

Gambar 11 Halaman Laporan Transaksi adalah admin tampilan admin untuk melihat pendapatan berdasarkan periode yang dipilih. Berisi detail dari tabel Transaksi dan Aksi, seperti mencetak ke printer.

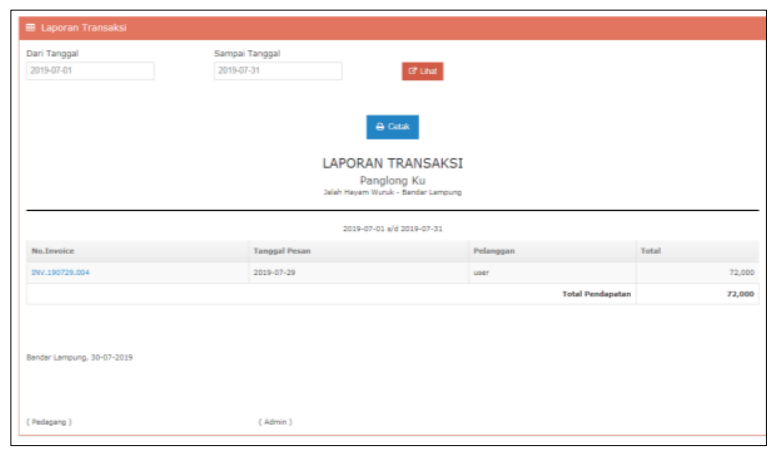

Gambar 11. Halaman Laporan Transaksi

Gambar 12 Halaman Laporan Rating adalah halaman yang memungkinkan admin panglong untuk melihat hasil penilaian berdasarkan periode yang diperlukan. Berisi detail dari tabel Rating dan Action seperti mencetak ke printer.

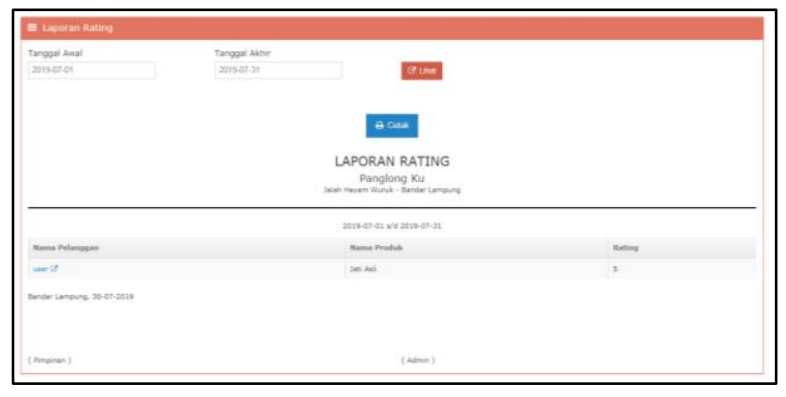

Gambar 12. Halaman Laporan Rating

Gambar 13 Halaman Laporan Stok berisi rincian dari tabel Inventaris dan Tindakan. Halaman ini adalah tampilan yang dimiliki oleh admin dalam melihat inventaris barang yang masih ada.

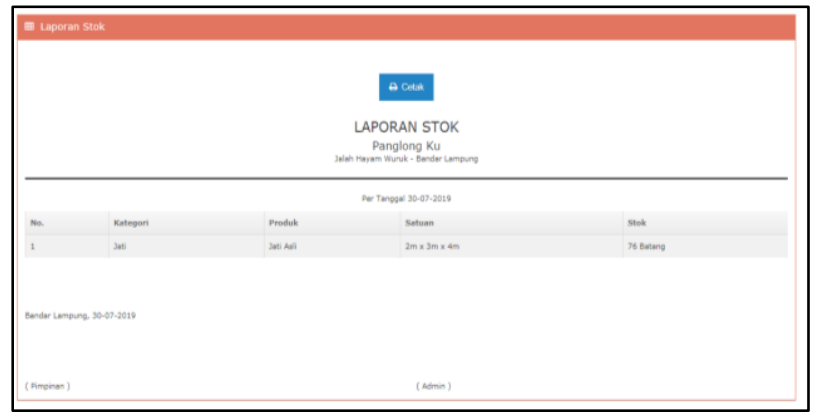

Gambar 13. Halaman Laporan Stok

\section{Kesimpulan}

Dari hasil pembuatan aplikasi e-marketing panglong kayu, disimpulkan bahwa dengan menerapkan sistem emarketing panglong kayu di Kota Bandar Lampung dapat memperluas pasar kayu dan memudahkan konsumen untuk memesan tanpa meninggalkan rumah atau tempat kerja, hanya dengan mengakses aplikasi e-marketing panglong kayu, memilih produk yang diinginkan, lalu transaksi pembayaran, produk yang dipesan diterima. Dari hasil pengujian perangkat lunak menunjukkan bahwa penerapan e-marketing panglong kayu memenuhi kreteria kelayakan. Penilaian kuesioner diukur berdasarkan skala linkert dan dikonversi berdasarkan kelayakan sistem konversi. Hasil uji kelayakan sistem dari aspek fungsional diperoleh nilai $93 \%$.

\section{Daftar Pustaka}

[1] Kosasi, S., 2014. Pembuatan Sistem Informasi Penjualan Berbasis Web untuk Memperluas Pangsa Pasar. Prosiding Snatif Ke-1 Tabun 2014 ISBN: 978602-1180-04-4 Sistem Informasi, STMIK Pontianak.

[2] Pangestu, H. et al., 2010. Pemanfaatan Aplikasi EMarketing Pada PT Jeah Untuk Memenangkan Persaingan Usaha. Jurnal ComTech Vol.1 No.2 Desember 2010: 477-492.

[3] Erlangga, E., 2014. Portal e-Brosur Berbasis Modern Advertising Methods Untuk Efektifitas Periklanan. Expert-Jurnal Manajemen Sistem Informasi Dan Teknologi, Universitas Bandar Lampung.

[4] Sari, M. A. \& Sari, R. P., 2014. Perancangan dan Pengembangan Web dengan Strategi E-Marketing pada PT.Columbindo Perdana. Jurnal Sistem Informasi STMIK GI MDP.

[5] Susanti, N., 2018. Perancangan E-Marketing Umkm Kerajinan Tas. Jurnal Simetris, Vol. 9 No. 1 April 2018 ISSN: 2252-4983.

[6] Wahirayasa, C. G. \& Kusuma, A. G. A. A., 2018. Peran E-Marketing Dalam Memediasi Pengaruh Orientasi Pasar Terhadap Kinerja Bisnis. Jurnal Manajemen Unud, Vol. 7, No. 6, 2018: 3291-3319 ISSN : 2302-8912. 
[7] Pressman, R. S., 2010. Software Engineering: A Practitioner's Approach, Seventh Edition. New York: Mcgraw-Hill.

[8] Schafer, J. F., Herlocker, J. \& Sen, S., 2007. Collaborative Filtering Recommender System. BerlinHeidelber: Springer-Verlag.
[9] Purwanto, S., 2009. Pembangunan Perangkat Lunak Sistem Rekomendasi Bursa Elektronis Telepon Genggam. Tesis - Insitut Teknologi Bandung.

[10] Sarwar, B., 2001. Item-Based Collaborative Filtering Algorithms. Minneapolis: University of Minnesota. 